\title{
Obituary-cum-Review Article
}

\section{ALLISON BUSCH (1969-2019), AUTHOR OF POETRY OF KINGS}

\author{
Imre Bangha \\ FACULTY OF ORIENTAL STUDIES, UNIVERSITY OF \\ OXFORD, OXFORD, UK
}

\begin{abstract}
Allison Busch: Obituary Note and Her Achievements
The academic community has learnt with great sadness about the untimely death of Allison Busch on 19 October 2019. She has been one of the most outstanding scholars of Brajbhasha poetry and early modern Indian culture. Her name has become indistinguishable from the study of the Hindi classicist rīti literature, courtly poetry.
\end{abstract}

Although she had a publishing history of hardly one and a half decades (one of her first articles appeared in South Asia Research 25(1) in a Special Issue on Pre-Modern Hindi Literature in 2005), she has injected new life into the study of classical Hindi in various ways. Bringing the often-denigrated rìti poetry into academic discourse is already an outstanding achievement. However, her contribution to our knowledge on Mughal India was even greater. She was one of the first western scholars who opened up Hindi poetry for the study of diversityconscious history. Before her work, classical Hindi was researched primarily within the field of religion, mainly related to Bhakti. What is now the triennial International Conference on Early Modern Literatures of North India (ICEMLNI) was Bhakti in Current Research even in 2000. The last decade of the last millennium had reinforced the attitude that the study of the early literatures in New Indo-Aryan languages needed to discard the legends that arose by reading its historical references at face value. A good example of this approach is the work by Charlotte Vaudeville (1993) on Kabir, which showed that we can hardly reconstruct anything historical about him. However, Busch's work changed the long-held view that Indian poetry is ahistorical. Her doctoral dissertation The Courtly Vernacular: The Transformation of Brajbhāṣā Literary Culture (15901690), submitted in 2003 at the University of Chicago, examined the historical 
momentum in which Sanskrit aesthetics was infused into the vernacular Brajbhasha. Her subsequent research further elaborated on the historical embeddedness of Hindi. Her approach to the subject, which twenty years ago was hardly conceivable, is widespread today.

In her brief career, Busch published several influential articles. She was also co-editor of the volume Culture and Circulation: Literature in Motion in Early Modern India (de Bruijn \& Busch, 2014). After the publication of this volume, she was engaged with two substantial projects, one on historical poetry in Hindi and one on the visualisation of Early Hindi poetry in miniature paintings, which will hopefully result in some posthumous publications. However, for now, Allison Busch will be remembered primarily for her monograph, Poetry of Kings: The Classical Hindi Literature of Mughal India (Busch, 2011). This book has opened new avenues in the study of Hindi courtly literature and it is worth revisiting it in some depth on this sombre occasion.

\section{Poetry of Kings in Mughal India}

Busch (2011) is a truly pioneering work in many aspects. Firstly, it is the first successful attempt to present Hindi court literature to a global readership. Secondly, it is one of the rare monographs that examine a facet of precolonial Hindi in a postcolonial light. Thirdly, and most importantly for a specialist of the era, it is a book that rehabilitates North Indian court literature with its rich aesthetic world and clears it from the stigmata that colonialist and nationalist historiography attached to it. It presents the history of rit $i$-literature as an organic development, which had its local beginning, spread over a vast geographic area, flourished in diverse contexts, and then declined. Moreover, we learn, for the first time, how deeply these developments are embedded in the social milieu of their age.

While reading the book, my first impression was that its ideas are self-evident and that I could identify with them so much that I should also have written them, though I could never aspire to the lucidity and brilliance of the author's academic prose. The reader does not feel the hard work that is behind it, as it is far from being written in a heavy academic language that tries to defend itself from every direction. Almost every sentence has an exciting turn and is a delight in itself. 
The book's subtitle uses the phrase 'Classical Hindi' to refer to what we call either Old Hindi or Early Hindi. In her communications, Busch clearly preferred 'early' over 'old', as the first term implies continuity with our modernity while the second suggests rupture. However, in the subtitle of her monograph she goes one step further. Although hardly used today, western students of Brajbhasha are familiar with the phrase from Rupert Snell's reader The Classical Hindi Tradition (Snell, 1991), which is still the best introduction to Braj poetry. The term 'classical' lends even more importance to the early, and rather neglected, literature of Hindi. Without knowledge of the classical, one cannot understand what is modern.

The volume starts with a discussion of the modern reception of riti poetry, and then follows up the development of this literature largely chronologically, reaching its colonial afterlife in the last chapter. In this way, this book about Hindi's past is framed within modernity. The Introduction demonstrates that the study of rìti literature has been trapped in paradigms of Mughal decline. Busch investigates the specific historical conditions that enable one culture to despise and largely forget their literary heritage while others embrace theirs. This is also the place where she introduces and problematises riti literature and its vehicle Brajbhasha, before presenting in more detail what happened to it under the second half of British colonial rule. Busch argues that during the early twentieth century, heartland intellectuals drawing upon reformist logic and nationalist thought radically transformed Hindi. By this process, many aspects of Indian culture came to bear the stigma of decadence and ritti literature fared particularly poorly under the new epistemological regimes of colonialism and nationalism and, one should add, Indian progressivism.

It should be noted here that nationalist epistemology was not unison in rejecting early Hindi literature. It also perceived this literature firstly as a link to a glorious classical past, which needs to be recovered and, secondly, as a welcome reform of the past literature with a view to expansion to the wider masses, indeed, to the entire nation. This is the reason why several histories of Hindi literature have been produced and a massive manuscript search was undertaken in the first half of the twentieth century. Hindi literature was presented as deeply rooted in the ancient past, the most glorious time of India, in two ways. Firstly, Apabhramsha came to be considered as 'Old Hindi' by many historians, and thus 
the history of Hindi could look back to about fourteen centuries. Secondly, Hindi was perceived as the modern continuation of millennia-old Sanskritic traditions primarily in its religious subject matters and in its aesthetics.

In our days, the real obstacle in the way of appreciating Brajbhasha literature is not so much grammatical as epistemological. Brajbhasha has a simple grammar, rather close to Modern Standard Hindi. Its prose texts, apart from some archaic words, would be easily accessible, had they not been composed in endlessly long sentences. The real difficulty of accessing Brajbhasha literature lies in a different perception of poetic language, which (1) has an unstandardised orthography, normally hesitating between Sanskritised tatsama and pronunciation-driven ardhatatsama spellings and in which spellings can be distorted to fit into metre, rhymes or alankāras, (2) has a more limited range of phonemes resulting in a high number of homonymous morphemes and lexemes, (3) can rely on an extended and often obscure Sanskritic vocabulary, (4) is elliptical with a penchant for omitting postpositions, and (5) might have mythological or cultural metadiscourse that is not readily understood today. Busch strongly underlines that the ambiguity arising from the above aspects was welcomed rather than avoided in Brajbhasha poems.

Chapter 1 on Keśavdās of Orcha is engaged with the beginnings of Hindi classicism since 'Keśavdās's signature contribution to literary history was to find ways of writing vernacular kāvya without sacrificing Sanskrit elegance' (p. 68). Why does classicism appear in a new idiom? This is one of the most exciting questions asked by the author. Naturally, an upcoming literary idiom can gain prestige by demonstrating that it is able to produce compositions that comply with the aesthetic rules of the most sophisticated and respected language. Yet, why would poets choose to compose in the vernacular when they have access to the cosmopolitan? In this context the discussion of language choice is particularly important. The answer proposed by a couplet attributed to Kabir, that the vernacular conveys freshness unencumbered by tradition is not relevant to the rit $t i$ tradition. Tulsīdās's idea that the vernacular 'asserts the primacy of innate expressive talent' (p. 26) is more relevant here. While the book rightly discusses the consequences of the choice made by Keśavdās, we also find that Keśav is reticent about the reasons for this choice. One can speculate that by the midmillennium, knowledge of Sanskrit had been restricted to a few and was definitely 
not as deep as in earlier centuries. This is indicated by the proliferation of corrupt Sanskrit inscriptions from the region (Willis, 1996). When the knowledge of a language is limited, composing poetry in it will become tedious and would indeed feel like a narrowly intellectual, rather than an aesthetic or emotional activity.

The book presents the early Brajbhasha bhakti poets and then Orcha's involvement with the Mughals. A particularly exciting part is the discussion of the poetic development of Keśavdās, since this poet will define the trajectory of the entire tradition. While the Rasikpriya $(1591)$ engaged with poetry closely based on the devotional traditions, the tone of the subsequent Kavipriya (1601) shifts. Busch observes: 'The overall ambience of the work is far more worldly' (p. 39) and gives a sense of the poet's intense engagement with court culture. Another engaging observation includes Keśavdās's manipulation of traditional Rāmāyaṇa imagery and on how his Rāmčandrika is replete with telling inversions of kāvya ideals. It is also interesting to observe how Keśavdās applies Sanskritic conventions on Jahangir and how he foreshadows the hybridity and multiculturalism that would become one of the defining features of later rìti literature. Thanks to Keśavdās, Brajbhasha classicism firmly established itself at the Mughal court. Subsequently, Braj poets at the court came to fulfil important functions (p. 55):

[The poet] taught the princes and courtesans the skills of poetry writing and connoisseurship; he beautified everyday life with his verses; he contributed to his patrons' noblesse and royal self-presentation, a kind of early modern equivalent of a public relations manager; he reminded the king of his duties to his subjects with learned disquisitions on rājadharma; he also served as a spiritual mentor. In short, Brajbhasha poets, like their Persian and Sanskrit counterparts, were vital to the larger cultural economy of a court.

The discussion of 'The Aesthetic World of Rīti Poetry' in Chapter 2 is perhaps the most interesting section for a literary historian. Here, Busch points out how poets blended tradition with innovation: 'Some of riti literature is deeply embedded in classical traditions of Indian poetics, such as alainkāraśāstra, rasa theory and nāyikābheda' (p. 65). The latter constitutes a complex typology of heroines that contributed, as Francesca Orsini (2019) also highlights, to the stigmatisation of 
ritti poetry. For the perceptive specialist, however, the expressive potential of the vernacular allowed more flexibility than did Sanskrit. The most conspicuous manifestation was the poetic ease in blending Persian, Sanskrit and local words. A further novelty was a heightened interest in historical genres.

This chapter also offers an excellent presentation of the major elements of rìt $i$ poetry. Through examples based on the theory of rasa, it discusses concepts, such as the ālambana vibhāvas (underlying causes) and the uddīpana vibhāvas (kindling elements), as well as the various phases of love and types of heroines. The introduction of an English terminology for indigenous concepts is a particularly welcome aid for those who will write about Hindi in the future. The author also rehabilitates the most popular structuring system of riti-poetry, the nāyikābheda typology of heroines, which 'encodes thousands of possible exchanges between lovers in poetry, allowing the kavikul [community of poets] to bypass the need for cumbersome background detail' (p. 86).

What were the new elements that Braj ritti-poetry added to classical Sanskrit? In form, it was rhyme and the possibility of mixing languages. In content, it was bhakti and historiographic interest. It is not just the words but also the reduced phonology and the flexible orthography that marks Braj out and opens an unprecedented range of sonic effects (śabdālankāras). For example, the avoidance of the retroflex 'ṇ' and the shortening of 'i', makes it possible to rhyme puni with guni (Skt guṇi). Brajbhasha poets also had a distinct advantage over Sanskrit in certain contexts because their language could interact with the Persianate world of Mughal India in ways that were foreclosed by classical tradition. Therefore, the poet-scholar Bhikhārīdās could speak enthusiastically of Brajbhasha as a literary language beautifully mixed with Sanskrit and Persian. I would also add here the possibility of imbibing poetic forms from its sistervernaculars, such as the pada, song with a refrain form, which seems to have been absent in Hindi before the sixteenth century but was present in Telugu and other vernaculars. Moreover, unlike Sanskrit, Brajbhasha never had any prescriptive grammar, which gave it unique flexibility. Consequently, for example, the perfective participle of the verb karnā (to do) in masculine singular, in contrast with the modern standard Hindi kiyā or Sanskrit krta-, can be put as kiyau/kiyo, karyau/karyo, kinhau/kinho, kinau/kino, kinha or kina and poets were allowed to mix them freely. This created an unprecedented capacity for sonic effects. 
Chapter 3 on 'Brajbhasha Intellectuals' examines their differences from and, especially, their attitudes towards innovations on the received Sanskrit models. While Sanskrit theory kept developing between the seventh and seventeenth centuries, Braj authors on aesthetics were not interested in introducing new theories. Their effort to show Brajbhasha as a continuation of the Sanskrit tradition prevented them from introducing radical changes. These Braj works were educational 'textbooks', rather than academic 'monographs'. Their innovation lay not in the theories they introduce, which they may have perceived as timeless and unchanging, but rather in how they present their material. A look at the opening passage of the Kavipriya $\bar{a}$ shows that the poet aimed to balance innovation with tradition. His attitude then set a model for later poets. Busch reminds the reader here of the distinction made by Sudipta Kaviraj between modern and premodern attitudes to cultural change: 'Modern rebellions announce themselves even before they are wholly successful; revolutions in traditional cultures tended to hide the fact of their being revolts' (p. 120). The eighteenthcentury poet-scholar Bhikhārīdās, the most innovative of rīti authors, both called attention to elements of change and sought to disguise innovation.

The loud claims for the lack of new theoretical and poetic approaches may also have been linked to the Persianate perception that Indian languages had only singers, but lacked poets. Even the most outstanding Sanskrit poet and literary theoretician of the seventeenth century, Paṇ̣itarāja Jagannātha, is called a musician in Persian court chronicles. One can add to this that Abu'l-Fazl's monumental $\bar{A}$ ' $\bar{n}$ - $\breve{e}$ Akbarī listed with examples 59 'poets of the age' and mentioned some more (Blochman, 1873: 548-611). All composed their work in Persian and no vernacular poets have been mentioned. Blochman (1873: 612-4) also listed singers separately, and this is where some Hindi poets are included. However, the fact that Akbar's time coincided with the heydays of classical Hindi poetry can hardly be guessed from Persian sources. Busch warns scholars that ' $[t]$ his fragmentation of knowledge across archives in different languages means that scholars with less linguistic range than their early modern subjects risk missing important parts of the story' (p. 164)

In spite of the rìti authors' declared continuity, as Busch points out, there are shifts in focus. For example, while the Sanskrit exemplar only has a religious 
veneer in its invocation, the love of the divine couple Radha and Krishna is ubiquitous in the Rasikpriyā. Thus, Busch concludes (p. 111):

Even if the poet does not always overtly link his bhakti to his intellectual positions, the obsessive parallelism of the Rasikpriya, in which nearly every single literary concept has to apply to both Radha and Krishna, may stem from Vaishnava values such as smaran (remembering the deity) and lìla (play of the divine couple).

Indeed, such attitudes penetrated other fields of early modern learning. For example, the Vaishnavas even produced a grammar of Sanskrit with a new grammatical terminology, the Harināmāmrta-vyākarana, in which punning references to the divine abound. Thus, knowledge and smaran became inextricably linked.

One of the most exciting discoveries of the book is that Braj authors also indicated that though they highly respected the Sanskrit aesthetic tradition, they were not uncritically following it. The recurring phrase apane mati anusāra (according to my understanding), long perceived as recusatio, stating of one's own incompetence, can also indicate that the poets consciously admit and defend their deviation from Sanskrit.

The discussion of 'Rīti Literature in Greater Hindustan' in Chapter 5 presents how Brajbhasha poetry supplants earlier, bardic forms of traditions enunciating royal prestige in the princely courts of Rajasthan with the case studies of Amber (Jaipur), Marwar (Jodhpur) and Bundi, and how it spreads beyond. It draws attention to the fact that while the Dingal bardic forms were predominantly oral, Rajput rulers developed libraries, possibly as an emulation of the Mughals, One should remark here that several of these libraries are preserved today, and in their collections Braj works figure prominently alongside those of cosmopolitan and other local languages. This composition of libraries also reflects the cultural interests of the time, all the more so as literature played a privileged role in the courts of early modern India. In the words of Busch (p. 179):

The literary arts brought grandeur, dignity, and beauty to courtly life, but they also helped to constitute the very atmosphere that made a court possible. 
Literature served rhetorical aims; it was educational; it also aided in the refinement of the nobility's moral and sensory faculties. ... Not all the world's kings were expected to be writers or scholars, however. This element of learning was particularly stressed in South Asia.

Much of this courtly literature was in the vernacular that was now able to produce both the 'elevated feel' of the Sanskrit classical kāvya, conveying the achievements of Sanskrit theoretical works, and at the same time was accessible to a wider range of people than Sanskrit would have been. From the middle of the seventeenth century, rìti literature spread beyond the imperial court.

First it reached courts closely linked to the Mughals through the mansabdāri system. While Rajput rulers, mostly allies of the Mughals, must have had at least some functional Persian that allowed them to participate in the Mughal universe, they developed their courtly literature around Brajbhasha, and not Persian or Rajasthani. While in the Mughal court Brajbhasha was one of several literary languages, in the Rajput milieu it became and remained the dominant one. It also had a wider scope there than at the Imperial court. For example, Rajputs patronised historical writings in the rīti genre while the Mughals preferred to write histories in Persian. I would like to add here that Dingal Rajasthani in the sixteenth century also had the potential for literature in the classicist style, as exemplified in Pṛthīrāj Rāţhaur's Velī Krisan-Rukmanī rī. However, Dingal lacked transregional aspirations and Mughal support, and this style did not take off.

The newly developed Rajput tastes for Brajbhasha rìti poetry soon spread beyond Rajasthan. One of the best examples is the Maratha rebel Śivājī who, among other strategies, enunciated his royal status by aligning himself with the new transregional Rajput court culture. As Brajbhasha classicist literature spread over much of western and central India, its practitioners were also able to move and define a new cultural space. In Chapter 6, 'The Fate of Rīti Literature in Colonial India', Busch argues that print culture made Brajbhasha works readily available well beyond the court, but these changes were quantitative shifts in numbers of readers, not qualitative shifts in literary theme. However, in light of more recent research, including that of Busch herself, this statement needs some qualification. By the early nineteenth century, rìti poetry deeply penetrated Indian 
society. Broughton's collection of The Popular Poetry of the Hindoos in 1814 first testified to the marked presence of ritti poetry amongst the villagers of Avadh. Moreover, shifts in themes can also be perceived in Braj poetry. For example, 'train poems' (rel ke kabitt) became a popular theme in the second half of the nineteenth century. The later poems in Hafizullah Khan's Hazārā, compiled in the same period (https://www.rekhta.org/ebooks/hafeezullah-khan-ka-hazarahafizullah-khan-ebooks) are good examples of late Brajbhasha tastes and poetry. Moreover, Robert van de Walle's article on Thakur Jagohan Singh (1857-1899), in the book co-edited by de Bruijn \& Busch (2014), also presents Brajbhasha's capability of depicting the new social environment.

Nevertheless, neither of these innovators were able to put into Brajbhasha the vigour necessary to compete with the upcoming Nagari Khari Boli literature. Literary activity became rather more inward looking, exemplified by the observation that most successful Braj works in the nineteenth century were anthologies structured by rīti categories. As Busch rightly points out (p. 211):

This coexistence of multiple production and reception modalities points to an interesting feature of nineteenth-century literary culture that belies the idea that poor outmoded riti literature came to an unceremonious end the moment that the British exhibited their more enlightened ways.

The anthologies were 'the most common way of conceptualizing literary collectivity... the organizing principle of which had nothing to do with historical time (p. 217). However, this is also the time of the first literary histories, those of Garcin de Tassy in 1839 and 1870-2, and Shivsingh Sengar in 1878. At this time, rìti literature was not perceived to be in decline. Busch also points out that print colonialism did not bring a rupture, and poets in the new Sanskritised Khari Boli still drew heavily on the Brajbhasha past. One of such continuities has been studied by Valerie Ritter (2011), who has pointed out that the special treatment of nature in the twentieth-century ČChy $\bar{a} v \bar{a} d$ poetry is in continuity with earlier Braj literature. My own research on Thākur also pointed at the same, but from a different direction. Sensitivities that have been singled out as modern have already been present in late Brajbhasha poetry prior to colonial modernity (Bangha, 2014: 29-37). 
In her conclusion, Busch draws attention to the importance of knowledge that can be gained from studying the Hindi past of the Mughal period and clearly points out what can be lost by failing to understand it (p. 243):

Some scholars of postcolonialism (who tend not to read precolonial sources in Indian languages) might hold that the precolonial past is forever unknowable because of the epistemic ruptures that attended India's colonisation. Some postcolonial theory also tends to be suspicious of textual forms of knowledge because colonial-period Orientalists privileged texts over practices, especially oral literary practices. Indians were of course great textualizers for two millennia before the colonizers came. Both the Sanskrit and ritti literary cultures are ample testimony to this, and it can hardly be sound intellectual-historical method not to weigh the precolonial evidence. Moreover, what could be more effective in countering India's cultural denigration under colonialism or in coming to terms with its devastating epistemological shifts than a rich, historically nuanced account of India's textual cultures before the colonizers arrived?

Busch also underlined the difficulties in accessing this past. They start with questions of accessibility of the archives and added questions of intelligibility. She stated that we need substantial philological and manuscript work, new texts need to be published and older ones reprinted, and we need translations. However, due to the postcolonial stigma on philological work, hardly any such work is appreciated in academia. Yet, there are enormous opportunities in turning to the vernacular archives of early modernity, since much of this material still lies unexplored and can shed light to so far unknown aspects of cultural history. This is becoming evident not only for North India, but notably also for South India (Weiss, 2019).

Several beautiful paragraphs towards the end of the book deplore the neglect of this literature and demonstrate the importance of studying it. Let me quote here one of them, as a precious legacy of Allison Busch (p. 245):

Quite aside from everything we stand to gain from a study of rìti literature- the joys of reading beautiful poetry, learning about the richly multicultural patronage contexts or the mechanisms of poetic performance and manuscript circulation in a preprint society—we gain access to past thought-worlds and unfamiliar modes 
of political life and sociality, including aesthetic processes of political incorporation and the importance of connoisseurship to community formation.

As a researcher working on the same field of classical Hindi, I cannot but fully endorse these words. In order to garner a new understanding of this important segment of India's literary past, Busch performs an 'archaeology of culture', trying to understand the forces behind this popular literary style on its own terms as closely as possible. Rìti poetry is notoriously difficult to understand. Its iconic figure, Keśavdās, has been often referred to as 'the devil of difficult poetry' (p. 67). This inaccessibility may have contributed to the fact that after the great generation of mid-twentieth century Hindi scholars, hardly any study presented new concepts on rìti literature. Busch has tackled her linguistically and culturally challenging material elegantly without giving much hint of how difficult it is to unravel the various layers of meaning in many of these poems.

This important book rehabilitates ritti poetry from the stigma of sycophant poetry of decline that has no relevance to the real world, a stigma given to it during colonial times, and maintained by a substantial segment of nationalist and, even more, of 'progressive' thinkers. We can learn from this that even a rejected form of poetic style, and indeed form of knowledge, can be appreciated if we aim to understand the world and the aesthetics that created it.

Although we lament the loss of a great scholar and the works that she now will not be able to produce, we also celebrate her achievements, through which the field of Early Hindi studies has gained new vigour.

\section{References}

Bangha, I. (2014) Scorpion in the Hand: Brajbhasha Court Poetry from Central India around 1800: A Critical Edition of Thākur's Kabittas. New Delhi: Manohar.

Blochman, H. (Tr.) (1873) The Ain i Akbari. Vol. I. Calcutta: Asiatic Society of Bengal.

Busch, A. (2011) Poetry of Kings. The Classical Hindi Literature of Mughal India. New York: Oxford University Press.

de Bruijn, T. \& Busch, A. (Eds) (2014) Culture and Circulation: Literature in Motion in Early Modern India. Leiden: Brill. 
Orsini, F. (2019, 25 October) 'Allison Busch's Immense Contributions Revitalised the Study of Brajbhasha'. URL (consulted 21 November 2019), from https://thewire.in/culture/allison-busch-tribute-brajbhasha

Ritter, V. (2011) Kāma's Flowers: Nature in Hindi Poetry and Criticism, 18851925. Albany: SUNY Press.

Snell, R. (1991) The Hindi Classical Tradition: A Braj Bhāṣā Reader. London: SOAS.

Vaudeville, C. (1993) A Weaver Named Kabir. Selected Verses with a Detailed Biographical and Historical Introduction. Delhi \& New York: Oxford University Press.

Weiss, R.S. (2019) The Emergence of Modern Hinduism. Religion on the Margins of Colonialism. Oakland, CA: University of California Press.

Willis, M.D. (1996) Inscriptions of Gopaksetra: Materials for the History of Central India. London: British Museum.

Imre Bangha

imre.bangha@orinst.ox.ac.uk 